\title{
Serum Creatinine Measurement
}

National Cancer Institute

\section{Source}

National Cancer Institute. Serum Creatinine Measurement. NCI Thesaurus. Code C61023.

A quantitative measurement of the amount of creatinine present in a sample of serum. 